DOI: 10.2478/RAE-2019-0024 Review of Artistic Education no. 182019 219-232

\title{
2. THE DIALECTICS OF INDUSTRIAL DESIGN VIZ-A-VIZ THE META - DESIGN PHENOMENON: The on-going Narrative / Implications for New Design Paradigms and Design Education
}

\author{
Obasuyi Osa-Francis Efe ${ }^{246}$
}

\begin{abstract}
The paper examined the dialectics and the Philosophical Theorization of the Phenomenon of Industrial design viz-a-viz meta-design, both as new areas of the philosophical discourse and intellectualization of both fields. This is not only as new subject disciplines / profession but also as New/Novel, and "uncharted waters" in the study and philosophy of both. Which is aimed at their adoption as a veritable tool and vehicle, for achieving New and innovative franchises and enterprises that might thus help bring about creating potentially New Design paradigms. In the body of the text it was established that by employing interdisciplinarity and collaborative efforts / approaches, designers try to achieve these New design efforts which are inspired by the way living organisms, systems and mechanisms, function and work. This eventually will influence, change or completely overhaul the way we feed, cloth ourselves, shelter, communicate or even co-habit in the future. The paper also established that the implications of the above will help engender a new narrative in the discussions and reasoning (or the dialectics) of these two disciplines and also of how they will affect the subjects practice and the various attempts aimed at its Pedagogy /Education. It was also established that the nature of such an Education and the Impartation of the adequate Design skills to graduates must adopt New strategies and implementation of an Industrial/Technological-based subject-Bias that leans towards Design intuitiveness, ingenious Technical/Technologically result oriented reasoning and practices. Bearing in mind the infusion also of various multidisciphinary subject areas that will help broaden the learner's horizon. The paper recommends that the issue of the Dialectics and phenomenology of Industrial Design/Meta design (which is the philosophical study of the structure and makeup (or consciousness) of the concepts, context and content of industrial design) must be embedded in the implementation of the three conceptual Approaches of Design which are:Design Awareness, Design Activity and Design Manufacture/fabrication. This is the sum total of all Design and Creative endeavours.
\end{abstract}

Key words: "Dialectics", "Phenomenology of Design" "Meta-design" "Interdisciplinarity" and "collaborative" approaches, "Design paradigms" "Autopoiesis and Allopoiesis"

\section{Introduction}

The Industrial Design Phenomenon is only approximately 150-200 years old in the five or six thousand year history of modern Human civilization. So the discourse or dialectics of the subject could be said to be that method of examining or discussion of opposing or consenting views and ideas aimed at finding out the truth about what the profession/discipline is all about, and also taking a look at what has been achieved so far. It is much like recalibrating the

\footnotetext{
${ }^{246}$ Associate Professor PhD., University of Benin, from Benin City, Nigeria, email: yandref2013@gmail.com
} 
parameters surrounding the story of modernism and post modernism while considering the societies/ civilizations that emanated there-from. The post Agrarian societies and era in Europe and America (coupled with those of the Medieval Cum-World War's $1 \& 2$,) never dreamt of a world, were life would become so much more easier and more conducive/comfortable to live in, due to the numerous inventions and innovations credited to the Industrial/machine Age of the Industrial Revolution of the 1800s. (Lucie-Smith, E. 2001)

Therefore the heralding of this Age brought with it not just remarkable successes in many respects, but with it came also numerous challenges attributable to that Age. The issues of mass production of goods and machine manufactured goods, couple with the issues of privatization and the glotting of the market with so much goods than could be sold, brought about stiff competition which became rife amongst product manufacturers. Who at the time were seeking out ways of improving their products to have that mass-appeal and consumer patronage over and above those of their rival manufacturers. The introduction of an improved means of communication and Advertising of goods and services all helped to speed up the process of ushering in the birth of a new profession and phenomenon called Industrial design ( Mitchel, C.T. 1993).

The eve of the emergence of this discipline/profession, saw the proliferation of Machine made goods needing that "human touch" of "craftsmanship and Aesthetic creativity" and input to help make the products more attractive for the consumers to buy. Be that as it may, the products were assumably first and foremost, made for Human consumption and not for "Robots". So this urgent industrial/ societal need helped trigger-off the birth of the new profession precisely in the early 1990s and one of the groups whose main influence was credited to this change came in the form of the Arts \& Craft Movement. Which saw the British Englishmen artist/architect - William Morris and the art critic/draughtsman John Ruskin - playing a Pivotal Role in seeing to this change. Collectively their works and activity in areas such as Graphic Design, Textile Design Painting and Architecture were so prolific that William Morris's printing press-The "Kelmscott Press" became synonymous, with the influences and activities of the Arts and craft movement. Which became the precursor and founding organization that helped pioneer the breakaway which led to the emergence of most of the various branches and professions, such as those of Architecture, Advertising, Graphic design, Textile Design, Industrial Design, Product design, to mention a few. Where disciplines such as Marketing, Aesthetics and Advertising were to follow much later. (Noblet, J. (ed) 1993).

The emergence of Industrial design and Designers came on the verge of the huge appetite for consumer goods and household appliances, such as the Washing machine, the Gramophone Player, Telephone, the Refrigerator, Television, the Automobile and Ariplane. This was further compounded by the rise and socio-economic prosperity of the middle class of the industrialized Nations. This presented a huge and enormous challenge for the manufacturers of 
consumer goods. This challenge became the driving force that propelled these Industrial Design professionals saddled with the responsibility for seeing to it that there is a change. The Aesthetics and Visual Dynamics (Image) of these products, became paramount. This being so serves to give them the desired consumer-induced appeal that will make them consumer friendly. This totally changed the dynamics, nature and face of our Man-made material culture and environment forever. (Hiesinger, K.B et al; 1993).

\section{The Phenomenology of Industrial Design and Meta Design}

First and foremost an attempt must be made to address the issue of phenomenology in Design. The Anthological meaning of the word phenomenon (or Phenomenology) is said to be derived from the Greek words "Phainomenon" which means "that which appears" and "Logos:" which means "study" or the "written word". According to Donald, L. (2013) who stated that "it has come to represent the philosophical study of the structure of experiences and cognition/consciousness of the concept, content or context of any subject matter". Continuing he said that "it is the systematic reflection (or style of thought) on the study of the structure and make up of the consciousness and the phenomena (events and happenings) that appear in acts of man's conscious nature. Which is aimed at determining the essential properties and structure of man's experience". Pierre, T. (1962) also opined that it is also the attempts at creating conditions for the objective studies of topics usually regarded as subjective in nature. Topics such as the contents of conscious experiences like judgements, perceptions and emotions are all included in this. Other schools of thought such as that of Michel, H. (2008), believes that it could also be termed to mean "an approach to philosophy which begins with the exploration of phenomena (ie anything that presents itself to us in conscious experience) as a means and an attempt to finally come to know what the absolute, logical and ontological/metaphysical spirit is, that is behind such a phenomenon". Stretching that truth a little further, the term could be expressed also, according to Smith, D. W. et al (2005) as "the reflective study of the essence of consciousness as it is experienced from the first-person point of view where phenomena is believed to be an intuitive experience that presents itself to us as a reflexion of such an occurrence".

In all of the afore stated the meaning and context of the phenomenology of Industrial Design viz-a-viz meta-design has come to represent that conscious nature of man, aimed at utilizing the contents of man's conscious experience, through cognitive Judgments and Innate perceptions of ideas and emotions that is aimed at arriving at an absolute, logical, metaphysical and conclusive object of man's design, called "the product" or "the product phenomenon". Hence this little in-road into all of the above discourse which was aimed at highlighting the importance, place and role of the meaning and essence of the word phenomenology in Design/Meta-design. 
Taking that Narrative for what its worth the word phenomenon as mentioned earlier is believed to be derived from the greek words "phainomenon" and also from the verb "phainein" which means to show, shine, appear, to be or to manifest itself. In other words according also to Michel, H. (2008) who says that it refers to "anything, events or happening which manifests itself in Nature or the subconscious". It could also be understood to mean (in its generic term) "things that appear or the occurrence of certain experiences. It is become known as what is experienced thus becoming the basis for reality". In the same context according to Ayer, A.J. (1984) the term phenomenon has come to be referred to mean "any occurrence, incident or thing, deserving of inquiry and investigation, especially events or things that are particularly unusual or of destructive importance" which sometimes occur in a design process or activity. While in its popular usage, the word phenomenon could be used to refer to some given extraordinary events, occurrences or happenings, that at first, defies any explanation or is baffling to the observer. Furthermore it could also refer to any occurrence worthy of note and investigation, that is often typically of an unusual event, person or fact that is of special significance. This is where the subjects and disciplines of Industrial Design and the Phenomenology of Meta design comes into focus. They both encapsulates all of the above content and context, as it occurs in their form, character and practice. They are the embodiment of sometimes the unusual, the unthinkable and often times defies any notable explanation in their application, meaning and approaches.

\section{Industrial Design: Implications, Meaning and Issues of New Design Paradisms vis - a - vis Meta Design}

The term "Design paradigms" are in themselves ascribed to represent distinct concepts, ideas or thought patterns, originating from the sociology of science. As its definition and meaning often applies to, models, roles archetypes, new and ideal/quintessential examples of solutions to how humans tries to resolve its numerous socio-economic and political problems. According to Wake. W. (2000) who states that a "design paradigm" or "a paradigmatic design" could be said to refer to a "design solution that is considered an exemplary, influential design solution, that will dictate or create design trends, which will become a model for success of the given product or design, as evidenced by its success in its market share and profitability in the marketplace". Good examples of these are the "Samsung", "Apple" and "Microsoft" or the Swiss Army knife design models or brands, to mention a few.

Also added to the above the meaning of design paradigms could also be attributable to their sociological roles/functions in society. For example, a design paradigm could refer to a "sociological paradigm" which is used to represent a group of collective beliefs, rules, norms, and other socio-behavioural tendencies. In this case such a design must be made to specifically suit such given society. Where in this case the design does not necessarily have to represent a set of 
particular societal solution to the given problem, but rather, according to Petroski, H. (1994) who states that they are a "presentation of a prescriptive system of ideas that could set in motion a given range of socio-cultural solutions that might become the "norm" and answer to the prevailing question besetting that society". The "QWERTY" keyboard design of the laptop is a very typical example of this type of Design Paradigm.

Design paradigms or Design patterns, as a terminology, is prevalent and commonly used in disciplines that cuts across Architecture, Industrial/Engineering design, including Design Education also. It could also be used to describe a given design solution or an approach to the various problem solving design initiatives. Design paradigms could be likened to a "Bridge" that connects "the old and the new" or "the known to the unknown". It is the functional equivalent of a physical entity that is used in various fields of applications that ranges sometimes from computer hardware to musical composition. From the aforetasted therefore, the implications and meaning of Design paradigms as they relate to Meta-design, is that of a symbiotic relationship. This infers that if the issues and the definitions of Design paradigms and their spheres of emphasis and applications, is shared by all of society in its attempt at providing solutions to the numerous socioeconomic/political challenges, it behoves therefore, that the new field of metadeign is not exempt from the influences and characteristics of the impact/implications of a new and future Design paradigms. As the discipline of Meta-design characteristically is structured as an emerging field and framework which is aimed at Redesigning, Redefining or the Recreating of social, economic, technological and technical infrastructures, where such new forms of interdisciplinarity and collaboration amongst designers and their design outputs can occur. Be that as it may, Meta design has come to represent an emerging industrial design trend and Approach aimed at resolving issues such as that of "Complexity Theory" and "Information design systems".

\section{Meta Design: The Phenomenon, Its Approaches and Processes}

The definition of Metadesign according to Giaccardi E. (2003) who stated that, "it is that conceptual framework aimed at defining and creating new socioeconomic and technical principles, theory/research, and infrastructures where-in, new forms of collaborative design or redesign which consists of a series of practical design-related techniques, tools and skills can be brought to bare for achieving those conceptual objectives in design. Continuing he stresses that It is to be considered "a new industrial design approach and methodology aimed at nurturing the emergence of prospects of collaboration of group/s of designers that cuts across and within interdisciplinary confines or boundaries. This new field was inspired by the way living organisms, system/mechanisms function. It is aimed at improving the way we live (feed, clothing, housing/shelter, 
communication) and the way overall societal inter-relationships are structured, attained and function.

According to Fisher, G. et.al.(2006) "Meta design has come to represent new design approaches aimed at the resolution of the complexity theory where the various communication and information systems are addressed, and they range from approaches in Biological disciplines, to techno-social and even techno-political spheres of influence and concerns," are addressed. Consequently the etymological or Anthological meaning of the word Metadesign originates from the Greek word "meta" which originally means "besides" or "after". In contemporary times it has been used to represent the "possibility of change or transformation" which also includes "self transformation". It could be ascribed to an aspect of design practice that (Re) designs itself.

At this juncture the term and concept of "Autopoiesis" becomes very relevant and incisive. The theory of the principle and concept of Autopoiesis, according to Evan, T. (2007) states that, it, "refers to the ability of a system to be capable of change, self creation, self organization, or self-transformation and reproduction. They are capable of automatic reproduction and self maintenance. The peculiarity of this system represent what takes place in the dynamics of the autonomy of living organisms, cells and systems. So the principles of Autopoiesis includes or aligns with those of the conceptual framework of an Autopoietic machine, product or design. For instance, it is a product or machine that is organized as a unified network of processes of production (transformation and or destruction) of components that are:

a. Capable of continuously regenerating and realizing these network of processes that produces them through their interactions and transformations.

b. These products or machines constitute a unified entity in space in which they exists, through its specification of the topological domain in which it operates (when the space is self contained). The biological cell or the "Eukaryotic cell" is a very good example of an autopoietic system or living system

c. It is an autonomous system that is operationally closed, in that there exists sufficient processes within it to ensure the maintenance of the whole unit/system.

According to Livingston, N. (1990) who stated that "an autopoietic system and its Antonym-Allopoietic system, is a contrast of one and the other. The Allopoietic system is for example like a car factory that uses raw materials (components) to assemble and generate or create cars. It is an organized structure or machine that represents something other than itself (ie the factory)". But if a parallel Analogy is to be drawn where the factory (system) is extended to include components in the factory's environment and spheres of influence, such as the supply chains, plant/equipment, machinery, workers, dealerships, customers, contractors competitors, the products (cars) spare parts and the whole Automotive industry set-up (that is geared towards sales and production of cars,) then it becomes a totally viable system, a living system that can be considered to 
be autopoietic in Nature. The principle of Autopoiesis according to Goosseff, K.A. (2010) can also be defined as "the ratio between the complexity of a system/product and the complexity of its environment where the systems are self-producing, not in the terms of their physical components but in terms of its organization". In other words they can be systems that produces more of their own complexity than the one produced by their environment. So the parallel relationship between an Autopoietic system and the process/practice of Meta design is in their complexities of the individual systems/ organizations that make up their structure and conceptual framework, such as the complexity of the multidisciplinarity of Meta design and or the concept and idea of Redesigning design itself. This behavioural model where the component units that might make up a Meta design team or system, can interact in multiple ways and might or will be required to follow specific (or sometime complicated) rules is in itself very complex to say the least. This interaction can culminate in a higher order of emergence, that can be greater than the sum of the parts (members, project to be redesigned) that makes up the Meta design structure or make-up. Furthermore, according to Vassao, C.A. (2010) who proposed that "the principle and idea behind meta design revolves around the notion that the future use of objects/ products and the consequent problems envisaged, emanating or encountered by the adaptation or usage of goods and services, cannot be sufficiently contrived at the design stage of the product/ service alone.

Consequently some definitions of Design, already viewed from the analysis of certain schools or thought states that, it could be said to be "the initiation of change in man-made things". Therefore it is hereby plausible to state that the "need for" or the "causative factor" for design is in most cases determined by its final state. In the same context the teleological perspective of Design puts it as "an economic payback or reward" at the point of sale and purchases or goods for the manufactures rather than the various stages of the products high performances and its value indicators, which is portrayed throughout the product's design life cycle. Meta design due to its very conceptual framework allows for the user interface with the design and designing process. It creates enough room for consumers to become designers or become part of the design process themselves. Meta design principles \& practice makes adequate room for changes at every level of the innovative process, including the metaphorical setting that brought about or sustains a given paradigm in the first place.

According to Wood, J. (2007) who stated that the Meta design concept basically "makes use of some conceptual techniques/tools". These techniques he says covers a wide range of applications and contexts. These according to him could be discussed using the following conceptualization tools or techniques, which includes the following:- 
(a) Stages and levels of Abstraction (This is the ability to understand the structure and limits of abstractions, the contextual approach and applications of given ideas.

(b) Visualization through sketches, Diagrams and Topology (this includes the use of visuals, sketches and diagrammatic representations and designs that are translated into 3 Dimensional/ Topological images.

(c) Algorithmic / Procedural Design (This involves the creation of 3D prototypes, models or Images that represents the real design initiative through the use of the step by step procedural techniques/approaches such as simulations using dummys, mock-ups or role play and or prototypes.

(d) Open- ended approaches - Emergence (This involves the adoption of an open-ended finality or if the need arises, of taking advantage of any envisaged, unintended or unforeseen results, which might create a new impetus for a new (or for another) design initiative resultative from those problems encountered.

\section{Issues of Dialectics as a Subject and its Implications on the Narrative of Design / New Design Paradigms. Dialectics - A brief Descriptive Analysis}

The issue of Dialectics and the various discourse and its interrelationship with industrial design that has necessitated or brought about this discussion of New Design paradigms, has been on-going for some decades now. As a result, to help us assimilate better the concept of dialectics in its core form and how it is applied to human thought and philosophy, an attempt shall be made to take a cursory look at some descriptive analysis of its form, meaning/definition and context of its usage as it affects the topic under review. According to Bertell, O. et al. (2008) who stated that the term Dialectics emanates from that branch of philosophy which according to him refers to "any formal system or discussion of reasoning by Dialogue of intellectual investigation and mode of exposing what is, and what is not, in order to elicit and arrive at what the truth or conclusion is, or should be". Continuing he says "It (Dialectics) uses (any) or the exchange of logical or superior arguments and or examples at arriving at such a conclusion".

Furthermore, Adler, M.J.(2000) in his body of work also asserted that "Dialectics is that method of discourse (not debate) between two or more persons, who holds a divergent or different points of views concerning a given subject matter. Where each of the concerned party is wishing to establish the truth by adopting (using) the reasoned forms of superior arguments to achieve their goals." In the same vane, Spramzi, M. (2011) puts forward an expanded dimension to the above where he says that "Amongst the concerned party (or one of them) may favour the "TRUTH" ( where the truth here could be referred to as the highest value of man's intellectual comprehension/ acceptability). That this truth could be discovered only through reason and logic that is proven during this discussion, reasoning and intellectual investigation. Where the role of Rationality, logic and intellectualism (which is proof and not of emotions) in this regard, is the proper means of persuasion and the right vehicle for the 
discovery of the truth. Where the truth here is referred to, or rather (according to Adler, M. J. (2000) while quoting "Socrates") means the "greater good". This infers that society should always seek the truth as a guide to the just and Egalitarian society we all seek. So how does this all relate to Industrial Design and the narrative of New Design Paradigms. The issue of this Design Discourse is therefore so apt when its placed side by side the issues and views put forward as to the meaning and essence of Dialectics as a field of study. The study, practice and Approaches of Design activity fundamentally seeks to establish that core Design Element or Truth which makes up the Core or the very Nature of any Design Initiative or endeavour. Design makes use of reasoning. Logic, Rationality and Intellectualism as the channels and vehicle for arriving at or for the discovery of the ideal and proper Design "Truth" that endures for the greater good of society, man and his environment.

To further embellish this notion therefore, we could attempt to drive the already accepted narrative and concept of Dialectics a little more by attempting to examine the Hegelian Dialectical position and concept, which is based on 5 (five) types of concepts according to George Wilhelm Friedrich Hegel himself quoted by Ayer A. J (1984) who stated as follows:-

- "That everything in life is Transient and finite as they all exist in the medium of Time and Essence.

- That Human History unfolds and it progresses as a dialectical process.

- That everything is made up or composed of opposing forces and contradictions.

- That quantitative change leads to qualitative change and that for the sake of change for change sake gradual changes leads to crises.

- That change in its innate nature is made up of a Helical/Spiral force and not circular."

The above 5 concepts further entrenches the Hegelian dialectical position which is hereby presented as three stages of development: A Thesis - which necessitates a reaction-: An antithesis - which contradicts or negates the thesis. The resultant tension between the two is usually resolved by means of:- A synthesis. The formula for any dialectic discussion according to Friedrich Hegel in Howard L.I.W. (1989), became - Thesis - Antithesis - synthesis or (Abstract - Negative - concrete). This became the Hegelian standard called "Hegelian dialectics". This view also holds true with the law of "the Negation of the Negation" which according to Ira, G. (1986) tends to support the position of "Heraclitus" who believes in the concept of dialectics as being "a unity of opposites and opposing situations or arguments" that is founded on the philosophy which according to Howard, L.I.W. (1989) states that "everything is in constant change due to the inner strife and opposition within the given object, circumstance or situation".

Some other concepts and positions of Dialectics relevant to the issue of Industrial Design under review, according to Petroski, H. (1994) proposes that 
the Dialectics of Design and its Implications on the resultant New Design paradigms could be stated to represent a "mode of thought or a philosophical/metaphysical medium through which an argument or idea and contradiction becomes the starting point or beginning rather than a dead end, in the attempt at getting to know the truth and trying to arrive at the given ideal Design Truth or Circumstance".

In the same perspective this type of concept could be used as a method of discussion that helps to maneuver the points of the opposing ideology into having to contradict its own position or thesis. Looking at it as a reasoned, logical and argumentative discourse (discussion) it helps to further or bring about the establishment of the desired truth. The process of Dialectics and Design interrogation always comes to an end when the ultimate Design truth is arrived at and its contradiction is diminished.

Deducing from all of the varied or variegated viewpoints on the issues of Dialectics and its implications on Design, it behoves therefore that the ideas and concepts inherent in the process of intellectualizing the investigation of the discussions and Reasoning, (on Design) that has to do with the concepts and content of industrial design and meta design, (be it in their activity, process). and practice, is all embedded in the Dialectical process and methods of investigation in Design. Where in the end, the truth which, in industrial design could represent the culmination of the end product or product design as had earlier on been mentioned. This is that which represents the "truth" or "end result" of all the lengthy and tedious process or activity of Design (Designing). The discussions, reasoning and contradictions still goes on even till today. Where for example, the role and place of the Designer in the design process has shifted from seeing him work under corporate leadership in order to help actualize the corporate business/industry strategy, to become the opposite. A new role has emerged, where designers now communicate directly and interface with the consumer or individual product end user. As products now have to infuse into their make-up, the products culture, aesthetics individualistic (personal) and other environmental attributes and concerns coupled with the ego or personal desires of the user, all becoming enclosed or embedded in the products final overall make-up. It is now the designers that come up with the Novel ideas of high-end, high-tech concepts and products that are now designed and made or produced in smaller series, being individualized and customized to fit and suit specific customer satisfaction. Sometimes products are produced and delivered to customer demand with 24 hours. This is the new Dialectics of a new era and New Narrative in the Design Industry of the New Millennia, the New reality and New Norm.

\section{The Dialectes of the Phenomen of Design and its Education - A Synthesis}

The debate (discourse) or dialectics about design has gone on now for upward of approximately 200 years or at least since the beginning of 
postmodern Europe and the New machine age of the Industrial Revolution. The discussions, debates, and or Dialectics still rages on till today. This is most evident and profound in an attempt at its definition of what it actually means. This is because the phenomenon of Design cuts across, barriers, boundaries of all socio-cultural and political divides as each sector attempts to see Design through its own "prism" or the "eye of the beholder" as it were.

Therefore according to Walker, A.J. (1989) the attempt at defining the term Design and also its education has seen (or has had to put up with) such "uphill" or sometime "Insurmountable" challenges such that the various groups (with sometimes parochial/ vested interests) has helped shaped and stifled the teaching and education of Design as a major discipline in schools (from primary to tertiary). As a result of this the early attempts at Design education has had to be made to adapt to the Teaching practices/ infrastructures that were already in place in the various traditional school systems. So saw the need for Design Educators to develop new, innovative and practical approaches to learning-based and practice-based, Design-led Educational principles and practice. An approach that will not only teach but will also be able to provide leadership skills, qualities and styles in the pedagogy and inculcation or impartation of the required skills for the take-off of the much needed Technological and Industry Bias, System of Education needed for todays Technologically Driven Industry and society.

According to O'Brien, J. et.al. (2008), who says that, over the years, design education as a phenomenon has grown in "leaps \& bounds" and has graduated from achieving Professional Training into a viable and recognized academic discipline and subject matter in its own right. While doing this, the subject has had to be manipulated to fit into and with the conventions of the traditional teaching across other traditional disciplines. As an act of improvement, Design Education has matured and graduated into modularized methods of teaching. In the area of Design research, for example it has adopted the practice - based research approach as it relates to the ontology of Design for example. The core of Design Education (in its content/context) now attempts to focus on the need for innovation, new teaching and new technologies which includes material science and technology, together with the new age of Robotics and Computer/IT. Technology, including the whole range of the CAF, CAM, $\mathrm{CAD}$, and CGI imaging; and the list goes on and on. With the consideration and the infusion of new multi-disciplinary subject areas that will help broaden the horizon of would be design graduates. This is intended and aimed at equipping the graduands to face the various design challenges they might encounter in the society and industry when they graduate.

So the new Design Educational approach as put forward by Kimbell, R. (2005) states that Design Education "has to be streamlined to cater to a Bais towards design intuitiveness, ingenious, technical/technological responses and result-oriented reasoning". From the above scenario therefore has emanated a 
fresh approach, designed to meet and achieve the following 3 objectives, steps and approaches:

- An approach that will direct students abilities towards a conscious and critical awareness of ethical, emotional and aesthetic values, applying technical possibilities, resulting in their ability to make valid intellectual Design decision which amounts to (Design Awareness).

- An approach that will extend and improve the graduates/ learners skills and faculty to be able to help them bring conceptual Design ideas into physical fruition which amounts to (Design Activity).

- An approach that will make conscious, the experience and satisfaction of this and other creative activity, that engenders creative abilities which will result in tangible products. This amounts to (Design manufacture/fabrication).

\section{Conclusions}

The Dialectics and the "Theorization" of the concepts and phenomenon of Industrial Design viz-a-viz Meta design has come a long way and the "journey" is not over yet. As the discourse and reasoning continues even till today. This is so because new and Novel discoveries/ frontiers in their theory and practice are being "unearthed" and they keep evolving by the day. It was established in the course of this research that the concept, practice and introduction of Meta-design put succinctly means, "The Redesigning of Designs" which is achieved by employing the interdisciplinarity approach which uses various collaborative efforts/approaches of designers that has helped unraveled or sometimes resulted in New Design initiatives or (and) New design paradigms. Such as those that come about and that has been inspired by the way living organisms/systems work and function. This represents the opening up of new vistas and fields of discipline that aims at improving the way humans feed, clothe, shelter, communicate and cohabit together. The issue of the phenomenology of Design viz-a-viz that of Meta design was also examined as being the study of the philosophical, content, structure and make-up of the consciousness of the concept, content and ideology of Design both as a subject discipline, and profession and the influences at the attempts at its pedagogy and Education. It was established that these attempts at its education must compulsorily adopt the following recommended three steps or approaches, which are firstly to direct students abilities towards a conscious critical Awareness of ethical, emotional and aesthetical values. Secondly, to extend and improve the graduates/ learners skills and faculty in order to bring their conceptual Design ideas into physical fruition and Thirdly to make conscious and help entrench all of the above stated facts coupled with all of the other creative activities that will help engender such creative Talents and abilities that will result in the production of Tangible physical products i.e Design manufacture/ fabrication. This is what Design is all about. 


\section{References}

1. Adler, M.J. (2000) "Dialectics" Routledge Press, London

2. Ayer. A. J. (1984) "Philosophy in the Twentieth Century". London: Unwin paperbacks Pub.

3. Bertell, O \& Tony, S. (2008) "Dialectics for the New Century" London. England, Palgrave Macmillan, Pub.

4. Donald, L. (2003) (Eng. Trans.) "Phenomenology of Perception:- Maurice Ponty" London, Routledge Press.

5. Evan, T. (2007) "Autopoiesis: The organization of the living": Mind in life: Biology Phenomenology, and the sciences of mind. Harvard Univ. Press Boston USA.

6. Fisher, G. \& Giaccardi, E. (2006) "Metadesign". A Framework for the Future of End use development". In Lieberman, F.P \& Wulf. V. (eds.) Kluwer Acad. Pub. Dordrecht. Netherlands.

7. Giaccardi, E (2003) "Principles of Metadesign: Processes and levels of Cocreation in the New design space. Kluwer Acad. Publishers. Dordrecht. Netherlands.

8. Goosseff, K. A. (2010). Autopoiesis and Meaning: A biological approach to Bakhtins super addressee. Journal of Organizational Change Management, University of Boston Press. Massachusetts. USA.

9. Hiesinger, K.B \& Marcus, G. H (1993). "Landmarks of Twentieth century Designs" New York. Abbeville Press.

10. Howard, L. I. W. (1989) "Hegel, Heraclitus, and Marxs Dialetic". Harvester wheat sheaf, Pub.London.

11. Ira, G. (1986) "Dialectical materialism": Its Laws, Categories and Practice, Petras Press NY. New York.

12. Kimbell, R. (2005) "Assessing Design innovation in Technology Education in New Perspectives, Research, Assessment and Curriculum development (eds) Lars Lindstrom Vol 17. Stockholm Inst. Of Ed Press/pub

13. Livingston, N. (1990) "Between Science and Literature": An Introduction to Autopoietics. Univ of Illinois Press. Illinois. USA.

14. Lucie-Smith, E. (2001) "History of Industrial Design", Oxford. Phaidon Press. UK.

15. Michel, H. (2008) "Material Phenomenology". Fordham University Press. New York.

16. Mitchel, C. T. (1993) "Redefining Designing" New York, Van Nostrand Reinhold Pub.

17. Noblet, J. (ed) (1993) "Industrial Design: Reflection of a century". Flammarion /APCI. Pub. Paris.

18. O'Brien, J. Millis, B. Cohen, M. (2008) “The Design Education course Syllabus". San Francisco: Wiley and Sons pub. 
19. Petroski, H. (1994) "Design paradigms; case Histories of Error and Judgement" in Eng. Design. Newtown Press. N. Jersey USA.

20. Pierre, T (1962) "What is phenomenology", Chicago, Quadrangle Books.

21. Smith, D. W. \& Thomasson, A. L. (2005) (eds) "Phenomenology and Philosophy of Mind", New York, Oxford University Press.

22. Spramzi, M. (2011) "The Art of Dialectics between Dialogue and Rhetoric" The Aristotelian Tradition, Philadelphia USA, John Benjamin's Pub.

23. Vassao, C. A. (2010) "Metadesign tools, Strategies and ethics towards complexity" Blutcher Pub. Sao Paulo. Briazil.

24. Wake, W. (2000) "Design paradigms". A source book for creative visualization. Adwark pub. London.

25. Walker, A.J. (1989) "Design History and History of Design", London. Pluto Press.

26. Wood, J. (2007) “Win-win: synergy tools for metadesigners". In Designing for the $21^{\text {st }}$ Century, Interdisciplinary questions and insights. (Ed.) Thomas Inns. Gower Pub. London. 